\title{
5.4. ОСОБЕННОСТИ БЮДЖЕТНОГО ПРОЦЕССА В ФЕДЕРАТИВНОЙ РЕСПУБЛИКЕ ГЕРМАНИЯ И ВОЗМОЖНОСТИ ИХ ПРИМЕНЕНИЯ В РОССИЙСКОЙ ФЕДЕРАЦИИ
}

\author{
Клокова А.Л., студент;
}

Кузнецов К.В., студент;

Плисова А.Б., к.э.н., доцент, кафедра «Государственный финансовый контроль»

\author{
ФГОБУ ВО «Финансовый университет при Правительстве РФ», г. Москва
}

В статье представлены результаты анализа нормативно-правовых актов Федеративной Республики Германия, регулирующих бюджетный процесс, выявлены особенности организации бюджетного процесса, дана характеристика основных этапов перераспределения бюджетных средств между регионами. Полученные результаты послужили основой для формирования рекомендаций, представленных в статье, по совершенствованию бюджетного процесса в Российской Федерации посредством внедрения алгоритма горизонтального выравнивания в ходе перераспределения финансовых ресурсов с учетом уровня расчетной бюджетной обеспеченности.

\section{Литература}

1. Бюджетный кодекс ФРГ [Электронный ресурc]. - URL : https://www.gesetze-im-internet.de/bho/index.html\#BJNR012840969BJNE001603308

2. Закон о распределении налоговых поступлений ФРГ (Zerlegungsgesetzt) [Электронный pecypc]. - URL https://www.gesetze-im-internet.de/zerlg_1998/BJNR199810998.html

3. Закон о финансовом выравнивании ФРГ (Finanzausgleichsgesetzt) [Электронный ресурс]. - URL : https://www.gesetzeim-internet.de/finausglg_2005/BJNR395600001.html\#BJNR395600001BJNG000100000

4. Закон об общих конституционных стандартах распределения ФРГ (Masstabegesetzt) [Электронный pecypc]. - URL : https://www.gesetze-im-internet.de/ma stg/

BJNR230200001.html

5. Министерство финансов ФРГ [Электронный ресурс] : офрициальный сайт. - URL: https://www.bundesfinanzministerium.de/Web/DE/Home/home.html.

6. Основной закон Федеративной Республики Германия [Электронный ресурc]. - URL : https://www.gesetze-iminternet.de/gg/index.html

7. Служба статистикаи ФРГ [Электронный ресурс]. - Режим доступа : https://www.destatis.de/EN/Home/ node.html.

\section{Ключевые слова}

Уровень бюджетной обеспеченности; перераспределение финансовых ресурсов; государственный финансовый контроль.

Клокова Анастасия Леонидовна

Кузнецов Кирилл Вадимович

Плисова Алла Борисовна

\section{РЕЦЕНЗИЯ}

Планирование и управление движением денежных средств является одним из важнейших направлений деятельности финансового менеджера, в том числе и государственного служащего. Оно включает в себя расчет времени обращения денежных средств (финансовый цикл), анализ и планирование денежного потока (составление бюджета движения денежных средств), разработку платежного календаря, определение оптимального уровня денежных средств и т.п.

На протяжении всего времени как предприятия, так и правительственные финансовые органы ведут расчет и оценку денежных потоков, проводят оценку финансового состояния, оценивают факторы, влияющие на величину денежных потоков, и т.п. Однако следует очень хорошо представлять себе, как пользоваться тем или иным инструментом, на что он годится, а для чего не подходит. Необходимо учитывать, что каждый конкретный случай индивидуален. Конечно, есть стандартные схемы, применимые в тех или других обстоятельствах, но это всего лишь схемы.

С точки зрения контроля в сфере государственных закупок уровень финансовой грамотности и качества финансового планирования и контроля должно быть намного выше, поскольку речь идет о бюджетном финансировании и влиянии расходов бюджета на рост социально-экономических показателей страны.

Поэтому представленная работа представляется нам чрезвычайно актуальной.

Изложение материала отличается логичностью, последовательностью. Проработан большой объем информации, в том числе новейшая законодательная база по рассматриваемыми вопросам. Следует отметить также логичность, последовательность построения работы.

Представляется, что научная статья А. Плисовой, А. Клоковой и К. Кузнецова «Особенности бюджетного процесса в Федеративной Республике Германия и возможности их применения в Российской Федерации» отвечает всем необходимым требованиям и может быть рекомендована к публикации в открытой печати.

Рябков О.А., Ә.э.н., доцент, профрессор кафедры экономики и инновационного предпринимательства ФГБОУ ВО «МИРЭА - Российский технологический университет», г. Москва.

DOI 10.38097/AFA.2020.95.70.013 
